\title{
THE EVOLUTIONARY IDEAS OF F. M. (LADIMIR) KLACEL, TEACHER OF GREGOR MENDEL
}

\author{
Margaret H. Peaslee ${ }^{\mathrm{a}}$, Vitezslav Orel ${ }^{\mathrm{b}}$
}

\author{
a Universiry of Pittsburgh at Titusville, Titusville, PA 16354, USA \\ ${ }^{b}$ Barvičova 51, Brno 60200, Czech Republic \\ e-mail: santavyj@fnol.cz
}

Received: January 23, 2007; Accepted: March 14, 2007

Key words: Breeding methods/Heredity/Natural science/Physiology/Philosophy

\begin{abstract}
A philosopher and teacher, F. M. (Ladimir) Klacel (1808-1882), educated in what is now the Czech Republic, developed his own explanation for the origin and interaction of living organisms. Klácel, a member of the Augustinian Monastery in Brno, influenced his younger colleague, Friar Gregor Mendel, who went on to formulate concepts in heredity that are still recognized for their profound insight. A mutual interest in the natural sciences of these two friends provided a basis for their discussions of the relationship between religion, evolution, and society. Klacel's outspoken defense of his proposals caused him to lose favor with both the Church and the authorities, and he immigrated to America in 1869. His failing health and inability to communicate with the English-speaking populace, unfortunately, limited his influence in his new environs.

In this paper we trace the roots of Klacel's philosophy and elucidate his incorporation of ideas from Hegel, Darwin, and others. An investigation of Klacel's recipe for a successful society reveals his belief in the universality of life and his optimistic hope for human achievement.
\end{abstract}

We see, believe and comprehend that everything that exists, grows and lives is directed by certain laws or intelligence; that in all diversity, things are mutually related through natural law; that this mutuality is graduated, as lower organisms combine and create higher ones; that the most complex and hence most perfect culmination of this development is the human being;

L. Klácel in the Voice of the Freethinkers' Union in America, 1872 (Laska, 1977, p. 97)

As soon as in the course of time the earth had achieved the necessary capability for the formation and maintenance of organic life, the first plants and animals of the lowest sorts appeared. . . Plant and animal life developed more and more abundantly; the oldest forms disappeared in part, to make room for new, more perfect ones.

G. Mendel in his 1850 examination paper on the geological formation of the earth (Orel, 1996, p. 62)

František Matouš Klácel (1808-1882) was a member of the Augustinian Monastery in Brno, having joined in 1827 , and continuing there until his emigration to America in 1869. The monastery had acquired an excellent reputation for the scholarly accomplishments of its friars, and the abbot from 1824 until 1867 was F. C. Napp (1792-1867), a distinguished scholar in his own right (Czihak and Sládek, 1991). Klácel had established his reputation as philosopher, author, poet, and patriot by the time Johann Gregor Mendel (1822-1884) joined the order in 1843.
Klácel's interpretation of evolution can be instructive when considered within the context of his previous interactions with Gregor Mendel, which took place before the appearance of Darwin's theory in 1859 (Darwin, 1859). In his 1850 autobiography written for permission to take the university examination in order to become a secondary school teacher, Mendel gratefully recalls advice received from learned men. Without mentioning anyone by name he was undoubtedly thinking of Klácel, fourteen years his elder, who was teaching philosophy at the Philosophical Institute in Brno during the period 1835 to 1844 . At that time Brno was the capital of the province of Moravia inside the Austrian empire ruled by the Habsburg monarchy.

By 1827 Klácel had completed his studies at the Philosophical Institute at Litomyšl in Bohemia. Much later in 1872, while living in America he wrote about his earlier decision: "I applied to a rich monastery of the Augustinian friars in Brno, whose head was a famous prelate, scientist, secret freethinker, and an expert in state affairs and economics" (Peaslee and Orel, 2001, p. 33). This prelate was the magnanimous abbot, F. C. Napp, who had recognized Klácel's ability and encouraged his further education. After finishing his three years' study of theology in Brno in preparation for the monastic life, Abbot Napp offered him the opportunity to study for his doctorate at Olomouc University. In 1835 before his graduation, Klácel was appointed professor of philosophy at the Brno Philosophical Institute. Having been influenced by Hegelian philosophy he began publishing a series of papers focused on humanism, patriotism, and the development of science and pointing to the importance 
of progress in the natural sciences. For his approach to students and his prudent explanation of lectured problems, Klácel was a most popular teacher. But in 1844 the Bishop of Brno accused Klácel of "pantheism and other heresies related to Hegelianism" and removed him from his professorship.

At that time Abbot Napp was an influential personality in the province, supporting the development of the sciences to be applied in agriculture, technology and teaching. His deep interest in the growth of scientific knowledge was acknowledged in 1841 when he gratefully accepted membership in the Royal Danish Society of Northern Antiquaries. The society had been established in 1829 in Copenhagen by the protagonists of prehistoric investigation, who had begun to elucidate the origin of the Earth according to the achievements in geological and paleontological investigation (Orel and Musil, 2004, p. 307). But Abbot Napp was unable to convince the Bishop of Klácel's innocence. With Napp's support Klácel was permitted to continue his study of philosophy and the natural sciences in the position of librarian of the monastery. With the death of the influential abbot in 1867, Klácel assumed that he had lost his life support in Brno and in 1869 , at the age of sixty-one, he immigrated to America.

Newly revealed documents, the foremost being the 168 recently-published letters between Klácel and his school fellow from the Philosophical Institute and later his closest friend, A. V. Šembera (1807-1882), allow us to trace the interpretation of the idea of evolution by Klácel ( 76 letters from Klácel and 92 from Šembera) in Brno and later in America (Fišer, 2003) in comparison with Mendel's view in the context of his studies in heredity. Šembera, after his graduation as a jurist, was appointed as a translator from German into Czech at the provincial presidium in Brno. Then in 1839 he became a professor of the Czech language at the Olomouc University and in 1849 at the University of Vienna. His brother, Václav Šmbera, was a member of the Augustinian Monastery in Brno.

The idea of artificial selection of animals and plants, introduced in the 1820s into the teaching of agriculture and the natural sciences at Olomouc University and at the Brno Philosophical Institute, provoked discussions among sheep breeders at their yearly meetings in Brno which focused on the theorization of breeding methods. In the 1830s Abbot Napp was among the protagonists encouraging the methods of physiological research in the search for an explanation of the basic questions of heredity. J. K. Nestler (1783-1841), a professor at Olomouc University, after more than 25 years of discussion on the improvement of breeding methods and acknowledgment of the difficulty of theoretical investigation, predicted that the investigation of Vererbungsgeschichte [history of heredity] or Entwicklungsgeschichte [developmental history] would develop from pedigree and trait records which had been maintained at breeding farms in Moravia for nearly forty years. In this context he also described artificial selection in sheep breeding using the analogy of the origin of new species through natural selection in nature. F. Diebl (1770-1859), professor at the Brno
Philosophical Institute, had been focusing attention on the investigation of the role of hybridization applied to the creation of new plant varieties. In 1843 Napp accepted Mendel into the monastery, and Mendel attended Diebl's lectures on agriculture and the natural sciences in 1846 during his study of theology. Thus Mendel and, indirectly, Klácel were acquainted with progress in the theorization of breeding methods and with the physiological research question formulated by Napp in 1837, "What is inherited and how?" (Wood and Orel, 2001, p. 9)

Shortly after Napp's election as Abbot in 1824, an experimental garden was established at the monastery where Friar Aurelius Thaler (1796-1843), professor of mathematics at the Philosophical Institute, collected and classified the local flora and carried out some of the first botanical experiments (Hrabětová-Uhrová, 1972). When Mendel came into the monastery, Klácel was managing the experimental garden. A year earlier Klácel published a booklet titled "Mostek, aneb sestavení skromných myšlének o tom, na čem každému záležeti má [A grouping of modest ideas in which everybody should be interested]" (Klácel, 1842, see Fišer, 2003, p. 90). It was an attempt to develop the first philosophical publication in the Czech language related to basic knowledge of natural science. Beneath the name of Abbot Napp, to whom the book was dedicated, Klácel listed Napp's memberships in public and scientific institutions. The last one entered is Napp's membership in the aforementioned Danish society, which neither the abbot himself nor his biographers ever cited. In his 1843 paper "O smrti [On Death]” Klácel proposed substituting the new word preroda [nature in regeneration] for the Czech work príroda [nature] to emphasize the permanence of evolution in nature. At the lowest level of development he placed inorganic harmony, where external forces govern motion and change. At a higher level of development he saw plants, whose sensitivity and capacity for growth are governed by an underlying organic force. Animals represent the next higher level, with the capacity for free movement and a rudimentary mind, possessing perceptible receptivity and instinct. Klácel placed the human at the pinnacle of development, representing a synthesis of all previous forms; he thus termed man a microcosm (Klácel, 1843).

Having been deprived of his beloved professorial rank in 1844, Klácel became involved in private studies of the natural sciences. In October 1845, Šembera noted in his letter to him the surprise of one of his friends that he occupied himself with botany, when he was expected to produce a book on esthetics (Fišer, 2003, p. 175). In April of the following year the deeply depressed Klácel, wrote to Šembera, "The whole day I am playing with plants and stones - not being able to dare to provide the other work” (Fišer, 2003, p. 204).” In July 1847 Klácel wrote to Šembera: "I am again writing. The day before yesterday I returned from Šardice and Čejč [villages in southern Moravia] and now I have already hay [meaning plants] which are valuable for observation.” Klácel intended to provide the plants for investigation during autumn and winter time in the monastery (Fišer, 2003, p. 215). In 1847 
he published the first Czech book "Dobrovéda [Ethics]" as volume VII of a new series called "Malá encyklopedie nauk [Small encyclopaedia of science]" edited by the Czech Museum in Prague (Klácel, 1847, see Fišer, 2003, p. 215). A volume on Esthetics was also expected from him. In his letter of September 29, 1847 Šembera encouraged Klácel: "The field on which you are now working is your life - here you are on your own place, here you have your appropriate and grateful readers, here you can be most effective" (Fišer, 2003, p. 10).

The year 1848 marked a watershed in the history of central Europe, and had a decisive impact on subsequent social and political development in the Czech lands within the Hapsburg monarchy. Revolutionary events in Vienna and other parts of the monarchy rekindled hope for new economic and social development in central Europe. On May 1, 1848 the Czech patriots in Prague created the Czech National Committee and announced the Slavonic Congress, consisting of delegates from Slavonic nations inside the monarchy. Klácel was elected as a delegate and worked in the section on education. In April 1848 he wrote to Sembera that he had been asked to teach philosophy [at the University in Prague] in the Czech language (Fišer, 2003, p. 222). At that time Klácel wrote from Prague to Friar A. Rambousek (1824-1901): "I entrusted a small garden [at the monastery] to our Gregor” (Dvořáková, 1976, note 1, p. 221). Shortly after the Congress convened in June, the Austrian army forcibly scattered the delegation, which squelched all hope for a national revival. During the revolutionary year of 1848 many requests had also been sent to the newly established constitutional imperial parliament calling for ecclesiastical freedom. A remarkable petition, signed by six Augustinians, was sent from Brno in August. In strong language the petition requested that they be permitted to devote their entire efforts, in accordance with their ability and past service, to public teaching and to enjoy free unity in an indivisible citizenship. Klácel's signature was the first on the petition with a note underneath, "teacher of philosophy." The style of the content reveals that he was the author. Mendel's signature was the fifth with the note, "candidate for teaching" (Orel and Verbik, 1984). An examination of the handwriting suggests he was the scribe. The petition received no consideration, because by this time the parliament had been forcibly suspended. But Bishop A. A. Schaffgotsch in Brno did not forget this rebellion. On an 1854 order from the Vatican he made a visit to the monastery and in his report he strongly criticized the community, mainly the scientific and teaching activities, as being contradictory to their spiritual calling. As an example he mentioned that Klácel had been forced to leave his teaching post. Abbot Napp acknowledged the faults mentioned and promised to fulfill the obligation of his community. But he successfully defended the existence of the monastery and its scholarly aspirations just at the period when Mendel was beginning his experiments in plant hybridization.

In his letter from Vienna in September 1849 Šembera recommended to Klácel that he plead for the post of professor of natural sciences at the newly-established Technical Institute in Brno. He recommended to him that he mention his many years of experience as a teacher, that he had established the mineralogical cabinet and created the botanical garden at the monastery, and that both these branches of sciences were his much loved occupation. According to Šembera Czech professor F. Diebl could substantiate Klácel's qualifications in the natural sciences (Fišer, 2003, p. 242). Self-critical Klácel in his letter written on October 5 expressed his embarrassment that he knew botany and mineralogy, but that he had never had a liking for the chemistry connected with mineralogy and had only a superficial knowledge of zoology. Therefore he agreed with the appointment of his friend J. Krejči (1825-1887) from Prague, later known as the founder of Czech geology (Fišer, 2003, p. 246). Of special interest is Klácel's letter to Šembera written at the end of November 1851. In it he asked "P. Gregor as mathematicus" [at that time Mendel was studying in Vienna] to visit Šembera and to inform him about the plans they had for "zaslibené [the promised land]" (Fišer, 2003, p. 267). According to the editor's note Mendel had the task of informing Šmbera about their dreams of immigrating to America.

In October 1848 Klácel was appointed editor of a new journal, Moravské noviny [Moravian News], in which he urged a renovation in public life with a greater attitude of humanism between people. He was influenced by the German book of L. von Stein on the development of a utopian socialism. In accordance with this he described his views on the solution of social problems using accounts of examples of evolution in nature, concluding that natural science should be the basis for social order. His utopian ideas were not well accepted by the public and toward the end of 1852 publication of the journal was stopped. In 1860 Klácel's authority in the natural sciences was acknowledged when he was named a member of the group of specialists who contributed the Natural Sciences section in Rieger's Encyclopaedia edited in Prague (Dvořáková, 1976, note 1, p. 121). Retrospectively Klácel's knowledge in botany was also confirmed in 1878 when H. Wawra wrote in his autobiography, written after his study of medicine in Vienna and having been a recognized ship's doctor, that during his studies in Brno he was introduced to the "ex-professor of philosophy and great botanist, who kept the herbarium founded by professor Thaler in the monastery and who supported him in his study of botany" (Vávra, 1985).

In 1868 Mendel was elected as the new abbot in the third round of voting. The voice of Klácel was influential in Mendel's success (Orel, 1996, p. 210). At that time the frustrated Klácel lost all hope for realization of his dreams in his homeland and decided to leave for America. In making the decision he did not acknowledge the warnings of his friends that at his age it would be very difficult to begin a new life in a country with a completely different cultural and social environment. In his letter of June 6, 1869 Šembera wrote, "I assumed that under your present conditions, with a pleasant and devoted ruler of the house [pod nynějším vlídným a Tobě oddaným vladařem 
domu] [referring to the new abbot Mendel], you would have abandoned the idea mentioned last year." He also warned him, "Do not believe that American hospitality and kindness is any different from that in other foreign countries, which persists for only a short time and ceases when the guest begins to be a burden." Šembera also reminded him of his secure existence in the monastery with the probability of finishing the book on Esthetics and the possibility of future cooperation in editing, such as the Czech encyclopedia (Fišer, 2003, p. 292).

Klácel, now the deposed professor of philosophy of the Brno Philosophical Institute and the unsuccessfully proposed professor of philosophy of the University in Prague, accepted the invitation of a Czech immigrant already established in the United States to become the editor of Czech magazines dedicated to politics, sciences, arts, and the mutuality of all Slavs. In the New Land he began to use the name "Ladimír," which was pleasing to him because of its harmonious combination of vowels. He was not successful, however, as a journalist for the regional magazine produced for Czech immigrants in America. He mingled his philosophical and natural scientific views, aiming for improvement of society, and this content did not appeal to readers. In 1906, long after the death of Klácel, some of his belongings were donated to the National Museum in Prague. Among his more than three hundred books are titles on medicine, chemistry, zoology, botany, and gardening. The following English books are in subjects similar to those studied in the German versions by Mendel in Brno: M. J. Schleiden's The Life of Plants; Charles Darwin's On the Origin of Species and The Variation of Animals and Plants under Domestication; Thomas Henry Huxley's Evidence as to Man's Place in Nature; and George Romanes' Animal Intelligence. Klácel and Mendel made nearly identical notes in the margins of these books, dealing with variation, heredity, and the mutability of species. These topics were of mutual interest during the years when Mendel was conducting his plant hybridizing experiments.

Most remarkable is Klácel's manuscript titled "Darwin" written in Czech, probably prepared as a lecture (Gabriel and Orel, 1972). Chiefly focusing on the philosophical aspects, he enthusiastically endorsed the theory of Darwin and the manner in which the German biologist, E. Haeckel, whom Klácel linked with Darwin, interpreted the theory of evolution. Klácel can be quoted, "There is no wonder that the teaching of Darwin and Haeckel, and of all who enquired into nature, has reached a wider circle of the educated public. In our opinion the teaching of the development of the later and higher degrees of life in nature from the previous, lower ones is already acceptable. We are pleased to learn that all life is united and that the existence of humans on earth is not an exception, but rather a supplement, to life on earth." On the next page Klácel, describing cross-breeding and survival of the fittest, concluded, "The breeder chooses for the propagation of domestic animals the most perfect individuals. Does not the same occur in nature? The one is artificial selection, the other natural selection. No animal is exactly like its parents. They [the opponents of the theory of evolution] are frightened when an explanation uses a human example." He connected the idea of evolution with heredity and wrote, "Everyone knows that differences occur in a prolific family. A long time ago I myself sowed the seeds from one pod, from one potato lobe, and what differences there were; yes, in one lobe there were seeds from which potatoes of different shapes grew up, such as we know." In the next line he mentioned Darwin's observations "of the great variations in size, color, speed, vigor, sharpness of outline, efficiency of limbs, etc., in the progeny of parental generations" with the remarkable conclusion, "But the more evident deviations are all heritable. Investigation of the laws of heredity, leads [us] to the seeds of animals and plants which give rise to the offspring and even to those [structures whose] dimensions [are] of extremely small size, which no existing microscope has yet been able to perceive. Here is a great task for microscopists and opticians."

Before leaving for America Klácel, like Mendel, had perceived and described the origin of new plant and animal species in accord with the teaching of agriculture and natural history in Brno and in accord with the explanation of the origin of the earth by geologists and paleontologists. Mendel, studying plant physiology in Vienna, was acquainted with the latest investigation of the processes of plant fertilization and plant hybridization. Returning from the university in Vienna he became captivated with investigation of "the law of the formation and development of hybrids" (Mendel, 1866). It was for him "one correct way of finally reaching a solution to the question whose significance for the 'Entwicklungsgeschichte' [developmental history] of organic forms must not be underestimated." For Mendel it was "impossible to draw a sharp line between species and varieties" and his species concept remained to be investigated. He also did not accept the concept of species stability (Müller-Wille and Orel, 2006). Before leaving for America, Klácel could have learned about Mendel's paper on plant hybridization. But being primarily a philosopher, he obviously failed to perceive the scientific thinking of Mendel and his theoretical explanation of the essence of heredity. Later Mendel used Darwin's name in his Hieracium paper and in his letters to C. Nägeli and described the "struggle for existence" when explaining the appearance of new species "which were better adapted to the prevailing telluric and cosmic conditions" (Mendel, 1870).

Living in America in permanent poverty and dependent on the support of friends, the frustrated Klácel often sank into disillusion and thought of his former safe life in the Brno monastery. V. Šnajdr, who met Klácel in 1878, said that plant science still aroused Klácel's interest. Even in America Klácel still thought of his life in the Brno monastery where "he was not alone in taking an interest in natural sciences, in the modern way of thinking," concluding that "in his friar Mendel he had an outstanding and devoted companion" (Šnajdr, 1908). 


\section{CONCLUSION}

A timeline to describe the progression of ideas described here could be proposed as follows: In 1859, after many years of deliberation, Darwin published his theory of natural selection as the method for producing new plant and animal species. Darwin found hybridization to be a perplexing obstacle and the laws of heredity were completely unknown to him. Mendel's contribution in 1865, through his scientific breeding experiments, clarified the concept of hybridization as the force for the creation of new plant forms. Klácel then, between the years 1869 and 1882 , assembled these contributions into a unified whole, accepting heredity as the raw material of evolution and realizing that microscopic examination of the units of heredity would be necessary for a complete understanding of "what is inherited and how."

Ronald L. Numbers has collected information about the experience and reactions to evolution and Darwinism of eighty American naturalists, biologists, geologists, and anthropologists elected to the National Academy of Sciences between its foundation in 1863 and the end of the century (Numbers, 1998, p. 137). Their described views can be compared with that of philosopher and naturalist, Ladimír Klácel, who lived in America from 1869 to 1882 . Arising from his private studies of the natural sciences in Brno and endorsing Darwin's theory of evolution through natural selection, Klácel also rose to the task of disclosing "the laws of heredity" and even suggested microscopic investigation for elucidating the units determining heredity. As a proponent of such research he encouraged Gregor Mendel and helped to create an atmosphere in Brno which contributed to its development. Given a better social position, more time and a scientific audience in America, he may have had a greater influence on scientific thought and been able to instill in more individuals his American motto: "Osmělme se zmoudreti [Let us not be afraid to grow wise]."

\section{REFERENCES}

1. Czihak G, Sládek P. Die Persöhnlichkeit des Abtes Franz Cyrill Napp (1792-1867) und die innere Situation des Kosters zu Beginn der Versuche Gregor Mendels [The character of Abbot Franz Cyrill Napp and the internal situation of the monastery when Gregor Mendel began his studies]. Folia Mendeliana, Brno 1991; 26:2934 .

2. Darwin Ch. On the Origin of the Species by means of Natural Selection: or, the Preservation of Favoured Races in the Struggle for Life. London: J. Murray; 1859. p. 502.

3. Dvořáková Z. František Matouš Klácel. Prague: Melantrich; 1976. p. 287.

4. Fišer Z. Korespondence Aloise Vojtěcha Šembery. Svazek 3, Listy Klácelovi [Correspondence of Aloise Vojtěch Šembera. Volume 3, Letters to Klácel]. Vysoké Mýto, Czech Republic: Regionální museum Vysoké Mýto; 2003. p. 321.

5. Gabriel J, Orel V. František Matouš Klácel a př́írodní vědy [František Matouš Klácel and natural science]. Sborník praci Filozofické fakulty Brněnské university, Řada filosofická. Brno, Fakulta 1972; B19:87-102.
6. Hrabětová-Uhrová A. Herbarium relics after J. G. Mendel in the Old Brno monastery. Folia Mendeliana, Brno 1972; 7:21-25.

7. Iltis A. Gregor Mendel's Autobiography. The Journal of Heredity 1954; 45: 231-234.

8. Klácel FM. Klácel's manuscript in Czech in 6 pages, titled, "Darwin," is preserved in the Náprstek Museum in Prague (shelf number B17). The Czech manuscript was published in: Gabriel J, Orel V. František Matouš Klácel a přírodní vědy [František Matouš Klácel and natural science]. Sborník prací Filozofické fakulty Brněnské university, Rada filosofická. Brno, Fakulta 1972; 19:87-102.

9. Klácel FM. Mostek, aneb sestavení skromných myšlének o tom, na čem každému záležeti má [A grouping of the modest ideas in which everybody should be interested]. Holomouc: Tisk Aloysia Škarniela, 1842.

10. Klácel FM. O smrti [On death]. Časopis Českého musea, Prague 1843; 17:329-347.

11. Klácel FM. Dobrowěda [Ethics]. Malá EncyklopedieNauk. Volume 7. Prague, Kronberg 1847.

12. Klácel FM. The creed of the freethinkers. Hlas jednoty svobodomyslných [Voice of the Freethinkers' Union]. June 3. Iowa City. As quoted in Laska, Vera. 1977. The Czechs in America, 16331977. Dobbs Ferry, New York: Oceana Publications, Inc. 1872.

13. Laska V. The Czechs in America, 1633-1977. Dobbs Ferry, New York: Oceana Publications, Inc. 1977. p. 152.

14. Mendel G. Autobiography. Manuscript in the Mendelianum (sig, no. 24), English translation by Iltis, Anne. 1954. Gregor Mendel's autobiography. The Journal of Heredity 1850; 45:231-234.

15. Mendel G. Versuche über Pflanzen-Hybriden [Experiments on plant hybrids]. Verhandlungen des Naturforschenden Vereines in Brünn, Abhandlungen 1866; 4:3-47. English translation by Stern, Curt and Sherwood, Eva R. The Origin of Genetics. A Mendel Source Book. San Francisco, California: W. H. Freeman and Company. 1966. p. 179.

16. Mendel G. Uber einige aus künstlicher Befruchtung gewonnenen Hieracium-Bastarde [On Hieracium-Hybrids obtained by artificial fertilization]. Verhandlungen des Naturforschenden Vereines in Brünn, Abhandlungen, 1870; 8:26. English translation by Stern, Curt and Sherwood, Eva R. The Origin of Genetics. A Mendel Source Book. San Francisco, California: W. H. Freeman and Company. 1966. p. 179.

17. Müller-Wille S, Orel V. From Linnaean Species to Mendelian Factors: Elements of Hybridism, 1751-1870. Annals of Science 64(2):171-215

18. Numbers, Ronald L. Darwinism Comes to America. Cambridge, MA: Harvard University Press. 1998. p. 216.

19. Orel V. Gregor Mendel, the First Geneticist. Oxford: Oxford University Press; 1996. p. 363.

20. Orel V, Musil R. Die Mitgliedschaft des Abtes C. F. Napp (17921867) in der Königlich Dänischen Gesellschaft für Nordische Altertümer [The Membership of Abbot C. F. Napp (1792-1867) in the Royal Danish Society of Northern Antiquaries]. Verhandlungen zur Geschichte und Theorie der Biologie 2004; 10:307-313.

21. Orel V, Verbík A. Mendel's involvement in the plea for freedom of teaching in the revolutionary year of 1848. Folia Mendeliana, Brno 1984; 19:223-233.

22. Peaslee MH, Orel V. F. M. (Ladimír) Klácel: Teacher of Gregor Mendel. KOSMAS: Czechoslovak and Central European Journal2001; 15(1):31-54.

23. Šnajdr V. Ladimír (František) Klácel. Jeho život a učení [His life and scholarship]. Dennice novověku 1908; 31(24):2-18.

24. Stern C, Sherwood ER. The Origin of Genetics. A Mendel Source Book. San Francisco, California: W. H. Freeman Company. 1966. p. 179.

25. Vávra M. F. M. Klácel (1808-1882) as inspirer of students in botany. Brno: Folia Mendeliana; 1985; 20:29-32.

26. Wood RJ, Orel V. Genetic Prehistory in Selective Breeding: a prelude to Mendel. Oxford: Oxford University Press; 2001. p. 323. 